(2)

\section{OPEN ACCESS}

\title{
Glossary: economics and health
}

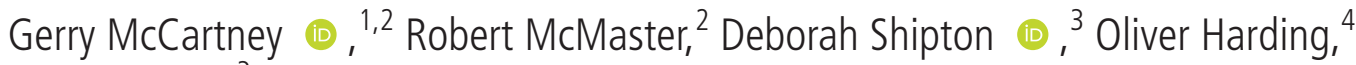 \\ Wendy Hearty ${ }^{3}$
}

${ }^{1}$ Clinical and Protecting Health, Public Health Scotland Glasgow Office, Glasgow, UK

${ }^{2}$ College of Social Sciences, University of Glasgow, Glasgow, UK

${ }^{3}$ Place and Wellbeing

Directorate, Public Health Scotland, Edinburgh, UK

${ }^{4}$ Public Health Department, NHS Forth Valley, Stirling, UK

Correspondence to

Dr Gerry McCartney, Place and Wellbeing Directorate, University of Glasgow, Glasgow G12 8QQ, UK;

Gerard.McCartney@glasgow. ac.uk

Received 14 October 2021 Accepted 24 January 2022

Check for updates

(C) Author(s) (or their employer(s)) 2022. Re-use permitted under CC BY-NC. No commercial re-use. See rights and permissions. Published by BMJ.

To cite: McCartney G, McMaster R, Shipton D, et al. J Epidemiol Community Health Epub ahead of print: [please include Day Month Year]. doi:10.1136/jech2021-218244

\section{ABSTRACT}

As we emerge from the COVID-19 pandemic, there is an increasing focus on how the economy is rebuilt and the impact this will have on population health. Many of the economic policy proposals being discussed have their own vocabulary, which is not always understood in the same way within or between disciplines. This glossary seeks to provide a common language and concise summary of the key economic terminology relevant for policymakers and public health at this time.

\section{INTRODUCTION}

The experience of the 2008 Great Recession, subsequent austerity policies in some countries, and the economic disruption caused by the COVID-19 pandemic and mitigating policy response, ${ }^{1}$ have for many reinforced the importance of the relationships between economic activity, the environment and population health and well-being. There have been calls for the economy to be 'Built Back Better' (or 'Built Back Fairer') in the wake of the pandemic, in recognition of the health and social problems that are inherent to the current economic system. ${ }^{2}$ The change in policy rhetoric towards designing, implementing and measuring the economic system differently has resulted in some new terminology being developed for people engaged in this policy area. However, 'obsessed as we are by results and action, we often forget to build a strong conceptual basis for our endeavours. There is nothing more practical than a good theory, but we lack a robust theoretical base for public health. We use everyday words that evoke different meanings in different minds and nobody seems too worried about it'. ${ }^{3}$

Given the importance of the economy for population health, and the live discussions on how best to design the economy as we emerge from the pandemic and face up to the challenge of climate change, this glossary aims to support public health efforts to inform economic decision-making by increasing understanding of key terminology and concepts. Complementary glossaries include economics and demography, ${ }^{4}$ health economics, ${ }^{5}$ econometrics, ${ }^{6}$ free trade agreements, ${ }^{7}$ social epidemiology, ${ }^{8}$ actions to tackle social inequalities in health, ${ }^{9}$ welfare states, ${ }^{10}$ power, ${ }^{11}$ work ${ }^{12}$ and the politics of health. ${ }^{13}$

\section{ECONOMY AND HEALTH}

Of all the factors that influence the health of populations, how our systems of production and consumption (i.e. social provisioning) are arranged is the most important. ${ }^{2}$ Social provisioning refers to processes of organising how to address people's needs and wants. The concept emphasises people's interdependencies and how society reproduces itself. ${ }^{14}$ Accordingly, the notion includes the fundamentals of caring and unpaid labour; power relations; ethical goals and values and so forth. Social provisioning is a focus of feminist economics and is rooted in Adam Smith's thinking. ${ }^{15}$

Population health (reflected in average, distribution and inequalities in health outcomes within a society ${ }^{16}$ is largely socially determined. ${ }^{2}$ There is now a substantial evidence base on how these systems of provisioning, the economy, impacts on the health and health inequalities within populations. ${ }^{17-20}$ Greater socioeconomic inequality is the most important cause of health inequalities, ${ }^{28} 20$ illustrated by the synchronous fall and rise of economic and health inequalities in Great Britain over the 20th Century. ${ }^{21}$

The net impact of recession on all-cause mortality during and immediately following recessions is likely to be small and beneficial; the increase in specific causes of death such as suicide is compensated by improvements in other causes such as road-traffic accidents and alcohol-related causes. $^{22}{ }^{23}$ However, the differential effects across the population can be profound. For those that become unemployed, mortality rates increase by about two-thirds. ${ }^{24}$ The response of governments to recession tends to be more important to population health than the recession per se. ${ }^{1825-28}$ For example, governments may respond through fiscal policies, such as austerity (reduced public spending and/or higher taxation) or stimulation (increased public spending and/or reduced taxation) or by primarily using monetary policy (such as quantitative easingincreasing the supply of money-or changes in interest rates). Since the 1970s, the dominant stance in Western economies, although to varying degrees, was to emphasise monetary policy responses with a passive fiscal stance. Furthermore, the relative priority afforded across sectors of the economy and to supporting the livelihoods and incomes of different socioeconomic groups is crucial. ${ }^{18}$ There is evidence that austerity policies lead to widening income inequalities and have adverse impacts on mortality and health inequalities. ${ }^{28-30}$

The strong association between economic development and growth and improvements in population health evident in the 19th and early 20th centuries appears to be weakening in high-income countries, ${ }^{22} 31-33$ and economic growth may ultimately be in tension with actions to address climate change. This is the existential global challenge for the 21 st century. Whether and how economies are changed to reduce greenhouse gas (GHG) emissions 
will increasingly become a major determinant of population health. Any discussion on the impact of the economy on health, therefore, needs to also consider the relationships to ecological sustainability. There are examples of policy options that could achieve positive outcomes for health, sustainability and equity ('superpolicies'). ${ }^{34}$ The design of the economy is crucial if such 'triple wins' are to be achieved.

\section{UNDERSTANDING THE LANGUAGE OF ECONOMIC POLICY}

Broadly, all approaches to studying the economy describe the economy in terms of consumption and production practices and how they are organised to provision individuals and populations. This involves various institutions, such as households, firms, markets and states. Political economy, a term closely associated with heterodox economics, refers to approaches that understand the economy as a complex evolving system in which individuals, populations and organisations attempt to address their needs, wants and aims. ${ }^{20}$ The economic system is shaped by historical and geographical contingencies, power relations, culture, values, legal systems and ecology. The economy is, therefore, seen as embedded in society and partially reflective of prevailing social values. $^{20}$

Heterodox economic approaches include various distinctive schools of thought, including, Austrianism, Marxism and Radical Political Economics, Feminist Economics, Post Keynesianism (which includes Modern Money Theory), Social and Institutional economics. Economics is usually synonymous with mainstream and earlier neoclassical economics, studies the economy as an equilibrating system in which agents (individuals, households, firms, organisations and governments) aim to maximise their welfare. Markets and prices are the focus of analysis. The economy is viewed as separate or separable from the rest of society.

There are various forms of money, including commoditybased (where value is carried in material-eg, gold), fiat (where value is legally assured, as is the case with electronic, paper and electronic national currencies) and local currency (where value is based on scarcity and trust). Money has three central functions: unit of account, store of value and a medium of exchange. How money is conceived informs the economic policies favoured. For example, Monetarists stress money as a medium of exchange, and, therefore, highlight issues of inflation (too much money chasing too few goods). By contrast, the Chartalist (or state theory) understanding of the emergence of money centres on its unit of account function, which entails credit and debt. On this understanding, money is a token of an obligation (a debt). This approach is the foundation of modern monetary theory in heterodox economics, which argues that states should not be treated in the same ways as households in respect to debt, and that a government that issues its own currency and has its debt denominated in that currency, cannot be bankrupted. State debt usually implies transfer of funds from the state to the private sector. These different understandings of money underlie the political differences in the economic responses to the financial crash in 2008 and to the COVID-19 pandemic. In 2008, state expenditures were primarily targeted at the financial system. Some governments, such as the UK, opted to stimulate consumption via short-term reductions in expenditure taxes. Thereafter, governments concerned about rising deficits increasingly adopted quantitative easing (increasing the money supply), again principally directed at financial bodies. By contrast, in the pandemic, governments have generally responded by fiscal expansion via increased expenditures across a broader range of sectors, of a greater magnitude, and for a longer duration.

Money is one of many forms of capital. In early economic work, capital often referred to the assets not embodied in people (eg, money, land or the 'means of production' (most frequently tools or machinery)) that was used in combination with labour (the work done by people) to create goods and services. Wealth refers to the ownership and possession of valuable capital, and different economic traditions are more or less concerned with its distribution. However, other forms of capital have more recently elaborated, most prominently by Bourdieu, to include cultural, social, human (usually conceptualised as education, skills and knowledge) and symbolic capitals that can be embodied and used in social differentiation and to maintain class privileges.

Most countries in the world have a capitalist economy. Although there are varieties of capitalism, they all share the characteristics of having: a legal system supporting individual property rights; widespread private ownership, markets and employment contracts; an extensive proportion of production organised separately from domestic activities and a developed financial system. ${ }^{35}$ Hall and Soskice argued that there are three types (or varieties) of market economies: liberal market economies, co-ordinated market economies and a hybrid. ${ }^{36}$ They are characterised in terms of industrial/employee relations, education and training, corporate governance and interfirm relations, and are associated with differences in socioeconomic outcomes such as income inequality.

A shift towards a liberal market economy is often termed as implementation of neoliberalism. This is when market forces are considered the optimal means of production and consumption and are encouraged across almost all areas of the economy, and when the role of the state is reduced to facilitating markets and competition. It is associated with privatisation, removal of barriers to trade, free movement of capital and limitations on the ability for workers and firms to organise (to enhance, for the neoliberals, labour market flexibility and competitiveness through antitrust regulations). Shifts towards neoliberal policies have been linked to widening health inequalities and excess mortality. ${ }^{182037}$ Neoliberalism often involves austerity policies in which there is a voluntary initial reduction in spending to achieve a particular goal. ${ }^{38}$ It is guided by the view that state expenditures (and debt) 'crowds out' private sector investment and thereby impedes growth (although total spending might not decrease much overall because of increased spending on unemployment benefits and public services). State austerity is, therefore, characterised by reductions in government spending and/or increases in taxation after accounting for 'automatic stabilisers' in the economy (such as changes in tax revenues or payment of unemployment benefits, which vary depending on whether there is economic growth or recession). Accounting for these automatic stabilisers is important for the measurement of austerity because of the inter-relation between government spending and revenue and economic growth/recession, and this allows for the impact of policy to be disentangled. Where there is a negative fiscal balance (ie, higher government spending than revenue, usually funded through borrowing or the creation of new money) this is termed fiscal stimulus. A standard Keynesian approach (named after the economist who advocated the approach) to the economy would see the use of fiscal stimulus (ie, increased government expenditure or reduced taxes) during periods of economic downturn and use of fiscal consolidation during periods of economic growth. In contrast, austerity is usually characterised by the implementation of fiscal consolidation during or following an economic downturn or recession. ${ }^{39}$ Austerity has been implicated as an 
important cause of the stalling in life expectancy trends after 2010 across many high-income countries. ${ }^{39}$

Welfare state typologies seek to describe common characteristics of countries around whether and how states meet population needs for, 'education, health, housing, poverty relief, social insurance and other social services'. ${ }^{13}$ The elaboration of common characteristics and their relationship to population health outcomes have been covered in detail elsewhere, but social democratic welfare states generally have better population health outcomes. ${ }^{18} 20$

A central objective of economic policy for many governments is economic growth. This can be defined as an increase in the overall real monetary value of goods and services produced, as measured by national income (or expenditure) in an economy over time. It is often measured in terms of gross domestic product (GDP, for goods and services produced within a particular country), gross national product (GNP, which includes incoming earnings and rents from abroad, but excludes outgoing earnings and rents from companies or individuals residing abroad) or gross national income (similar to GNP but includes the incomes of national citizens wherever they reside). ${ }^{40}$ They are useful measures of economic activity but have limitations. First, they only count commodifiable activities (eg, they do not count domestic labour unless it is paid for, nor illegal activities). Second, they sum spending on both desirable and undesirable goods and services (eg, pollution clean-up, investigating crime). Theoretically, need for economic growth is predicated on the idea that 'wants' are insatiable and that scarcity will, thus, always be present. Growth is however an attractive strategy in low income countries with growing populations.

\section{ECONOMIC INEQUALITY AND ITS RESPONSES}

Economic inequality describes the degree to which economic opportunities and resources (including income and wealth) are equally or equitably held and experienced across or between social groups or between populations. Within societies, economic inequality is influenced by the nature of the relationships between socioeconomic groups, ${ }^{41}$ which in turned are structured by social class, race, ethnicity, sex, power and intersectional relationships ${ }^{18-2042-44}$ (the study of which is sometimes referred to as stratification economics). ${ }^{45}$ Most countries have experienced increases in income and wealth inequalities over the past four decades, with variations in the timing and extent. There are various explanations for this, including income gained from the ownership of capital assets growing at a faster pace than national income growth ${ }^{46}$ to the underlying organisation of society privileging particular socioeconomic groups. ${ }^{47}$

One important mechanism which has exacerbated economic inequalities is rent. ${ }^{48}$ In owning or controlling an asset (ie, wealth), individuals or firms receive an income stream (rent) as a result of their ownership of that asset. Assets can adopt a variety of forms, from land, financial, intellectual property rights, ownership of natural resources, digital platforms, to service contracts and infrastructure. ${ }^{48} 49$ The owner of the asset does not necessarily need to do anything productive in order to receive rent (as is the case with shareholding), although it can involve forgoing the personal use of the asset (eg, a second home) or require some spending to extract the rent (eg, hiring a landlord service); their ownership rights enable the generation of income. Rentierism, the practice of extracting rents, is increasingly prevalent in Western economies and has contributed to rising income, wealth inequalities and health inequalities. ${ }^{18-20}$ Extractive economies are those where wealth and power become concentrated among elites through the imposition of rents and are termed 'extractive' because this practice removes assets from the majority of the population without creating new wealth.

A specific aspect of economic inequality is poverty. This can be defined and measured in several ways. It describes the experience of material and/or social deprivation and the inability to fully participate in societal norms. In the consensual approach, these norms are defined by the public and should allow for individual choice. This generates examples of the experience of poverty, such as an inability to afford to buy a birthday present for your child to be able to attend a birthday party without shame (https://www.poverty.ac.uk/definitions-poverty). In practice, relative poverty is often measured as a household income less than $60 \%$ of the median, and absolute poverty as the inability to buy essential goods and services (as with the Minimum Income for Healthy Living). ${ }^{50}$ Deprivation indices attempt to capture the broader experience of poverty but are less frequently available at individual or household level (except through specific surveys) but are widely available as small area indices which average the experiences of populations living in the same area. Poverty is an important cause of a wide range of adverse health outcomes. ${ }^{20}$

Economic inequality is also experienced intersectionally. Feminist economics is characterised in several ways by its focus on gender (in)equality and its explicit and systematic inclusion of all forms of provisioning (including unpaid and domestic work), which are often omitted in 'mainstream' economics and measures of economic activity, such as national income. It also recognises that gender relationships and differential impacts matter for understanding economy.

In recognition of the range of health and social problems caused by economic inequality, a series of counter responses have been proposed. Community wealth building has been defined as a, 'people-centred approach to local economic development, which redirects wealth back into the local economy and places control and benefits into the hands of local people'. ${ }^{51}$ (see www.cles.org.uk). The approach is designed to be implementable using the powers available to local, city and regional governments, draws inspiration from initiatives in the Basque Country (eg, Mondragon), Cleveland and Preston ${ }^{51}$ and attempts to redesign the economy and reset economic relationships in order that inequalities reduce. Five pillars of community wealth building have been described. Plural ownership of the economy (eg, municipal ownership and cooperatives); making financial power work for local places (eg, using pension funds and mutually owned banks as a source of investment); changing employment and recruitment practices to support increased fairness and justice; and adapting procurement to create greater equity through supply chains and supporting socially productive uses of land and property.

Anchor institutions are organisations which, 'have an important presence in a place, usually through a combination of: being largescale employers, the largest purchasers of goods and services in the locality, controlling large areas of land and/ or having relatively fixed assets; (and which are) tied to a particular place by their mission, histories, physical assets and local relationships)'. ${ }^{52}$ Examples include local authorities, hospitals, universities, large local businesses and the community and voluntary sectors. Anchor institutions are, therefore, mechanisms for reducing economic inequalities and generating positive social outcomes through community wealth building. In contrast, the movement, withdrawal or privatisation of an existing anchor institution can have the opposite effects. ${ }^{53}$

Economic democracy describes the extent to which economic power is shared across populations and is one of the strands of 
community wealth building. ${ }^{54}$ Cumbers et al argue that economic democracy can be viewed in terms of rights and abilities to participate in decisions relating to consumption and production. Other conceptions focus on forms of ownership and participation in firms (including municipalisation, publicly owned companies, social enterprises and co-operatives). A broader description of economic democracy includes four components:

- 'workplace and employment rights, (including the) levels of employment protection and insecurity, employee participation and managerial attitudes;

- (the) degree of associational economic democracy, involving levels of trade union organisation, employers' organisation and collective ownership (such as co-ops and credit unions);

- (the) distribution of economic decision-making powers ... [e.g., measures of the concentration of economic power strength of (the) financial sector, (and the) geographical concentration of government fiscal powers...];

- and (the) 'transparency and democratic engagement in macroeconomic decision making' (for example, the extent of different social partners in decision making, accountability and levels of corruption and central bank transparency)'. ${ }^{55}$

Particular policy proposals, such as a Citizens' Basic Income $(C B I)$, have been proposed as a means of reducing economic inequality and to respond to the changing nature of work. CBI can be defined as an income that is paid: unconditionally (although different levels can be introduced across age groups); automatically on a regular basis; is non-withdrawable (ie, it is not mean tested); is paid to individuals not households and as a right of citizenship (see www.citizensincome.org). There is some evidence that schemes similar to CBI may improve some health outcomes although there have been few examples of similar policies introduced in high-income countries in the last few decades. ${ }^{56} \mathrm{CBI}$ is synonymous with 'Basic Income' and 'Universal Basic Income'. Implementation of a CBI requires alignment of the CBI with other social security and tax policies in operation if it is to be truly non-withdrawable. ${ }^{57} \mathrm{CBI}$ differs from a Minimum Income Guarantee, which seeks to create an income floor for a population through a combination of social security benefits, wage subsidies and pay (eg, https://neweconomics.org/ 2020/03/building-a-minimum-income-protection).

Another proposal has been Universal Basic Services, which seek to provide a sufficient and wide range of services, in negotiation with the public, and free at the point of need/use to ensure equitable access (https://neweconomics.org/2020/02/the-casefor-universal-basic-services). It links to the idea of a foundational economy, which refers to the production of 'goods and services which are the social and material infrastructure of civilised life because they provide the daily essentials for all households' (eg, utilities, internet, education, health and social care, roads and banking) ${ }^{58}$ It is argued that the foundational economy is an essential underlying component of the economy and political economy more generally, but that it is often overlooked, underresourced or misused as a source of private revenue.

Some approaches to economic policy have focused on creating inclusive economies. These have four distinct attributes: an economy that is designed to deliver inclusion and equity; equitable distribution of the benefits from the economy (eg, goods, services, power, value); equitable access to the resources needed to participate in the economy (eg, health and education) and operates within planetary boundaries. ${ }^{59}$ They are distinct from 'inclusive (economic) growth' as a concept because inclusive economies are neutral in relation to whether the size of the economy changes over time. In contrast, inclusive growth focuses on a form of economic growth which leads to a more equal distribution of economic benefits across societies. Levelling-up is a term used by the current UK Government, which is underdefined, ${ }^{60}$ but arguably seeks to reduce geographical inequalities by catalysing faster economic growth in poorer regions. The term has also been used to describe how health inequalities can be reduced by increasing the health more for those in lower socioeconomic positions that those in higher positions, thereby reducing the social gradient in health. ${ }^{61}$

There has also been substantial work to understand how changes in workplaces can narrow economic inequalities and improve health. The definitions and relationships between employment, underemployment, precarious employment and health have been covered in detail elsewhere. ${ }^{12}$ However, new terms such as 'fair work' and 'good work' have emerged in recent years in recognition of possible increases in unfulfilling and precarious work, underemployment and long hours for different groups of workers, and a rise in in-work poverty. In Scotland, a Fair Work Convention was established and articulated five dimensions of fair work: effective voice, opportunities, security, fulfilment and respect (https://www. fairworkconvention.scot/). A similar series of components have been described by the Trades Union Congress for good work (https://www.tuc.org.uk/sites/default/files/extras/goodwork.pdf).

\section{ECONOMIC ROOTS OF ECOLOGICAL (UN)SUSTAINABILITY AND ITS RESPONSES}

The threat of ecological sustainability for population health is now well recognised, as are the economic causes of climate change. Ecological sustainability is often defined as the ability of meeting present needs without compromising the ability of future generations to meet their needs (eg, by depletion of natural resources faster than they are created, or through the accumulation of waste products faster than they can be broken down). Well-being economies is 'a broad term designed to be inclusive of the diverse movement of ideas and actions striving towards this shared vision: an economy that delivers social justice on a healthy planet' (https://wellbeingeconomy.org/about), and which combines a concern for reducing economic inequalities with ecological sustainability. Many advocates of this approach argue that deprioritising the pursuit of economic growth allows for a redesign and reprioritisation of economies towards the achievement of social and ecological outcomes. ${ }^{62}$

The extent to which the current economic system can become ecologically sustainable depends on decoupling (where economic growth does not create increased GHG emissions or ecological damage). ${ }^{63}$ There is substantial policy and academic debate about whether decoupling has been happening or could happen in the future. There is an important accounting issue for such calculations, as some high-income countries have been able to decouple, but only on the basis of moving their GHG emissions to the countries from which they increasingly import manufactured goods. Those who are committed to avoiding climate change by reducing GHG emissions can be divided into those who argue that such reductions are compatible with (or even require) continued economic growth (eg, to deliver improved technologies), termed sustainable economic growth; those who believe that economic growth is incompatible with continued economic growth and, therefore, argue that a managed decline in total economic activity (ie, degrowth) is required; and those who are agnostic on economic growth as long as reductions in GHG emissions are achieved. The 
Table 1 Examples of work to broaden the theorisation and measurement of societal progress beyond economic growth

\begin{tabular}{|c|c|}
\hline Organisation & escription \\
\hline Trust & $\begin{array}{l}\text { Gross Domestic Well-being is proposed as an alternative measure of societal progress, covering social, economic, environmental and democratic } \\
\text { outcomes, and producing a weighted summary measure derived from these (https://www.carnegieuktrust.org.uk/project/measuring-what-matters/). }\end{array}$ \\
\hline $\begin{array}{l}\text { Organisation for } \\
\text { Economic Co-operation } \\
\text { and Development }\end{array}$ & $\begin{array}{l}\text { The Better Life Index was created in response to the Commission on the Measurement of Economic Performance and Social } \\
\text { Progress (the 'Stiglitz commission') and has attempted to provide a basket of indicators (including housing, jobs, education, civic engagement, life } \\
\text { satisfaction, work-life balance, income, community, environment, health, safety) that can be weighted differently to provide an overall measure of } \\
\text { societal progress, and compared between countries and by gender (https://www.oecd.org/statistics/better-life-initiative.htm). }\end{array}$ \\
\hline Oxfam & $\begin{array}{l}\text { A Humankind Index was developed through a participatory process to define a new measure of prosperity. It weights measures of: housing; health; } \\
\text { neighbourhood environment; satisfying work; relationships; safety; and access to different kinds of spaces and services (https://policy-practice.oxfam.org/ } \\
\text { resources/oxfam-humankind-index-the-new-measure-of-scotlands-prosperity-second-results-293743/). }\end{array}$ \\
\hline Scott & $\begin{array}{l}\text { The National Performance Framework is a broad and comprehensive approach to regularly monitoring progress towards achieving national outcomes } \\
\text { across early years experiences, local communities, culture, the economy, education, the environment, employment, health, human rights, international } \\
\text { contributions and poverty (www.https://nationalperformance.gov.scot/). }\end{array}$ \\
\hline $\begin{array}{l}\text { Sustainable } \\
\text { Development Solutions } \\
\text { Network }\end{array}$ & $\begin{array}{l}\text { The World Happiness Report is based on survey-based measures of 'life evaluation' and positive and negative emotions as measures of societal } \\
\text { progress (https://worldhappiness.report). It is linked to the 'WELLBY' - the well-being experienced by populations each year. }\end{array}$ \\
\hline $\begin{array}{l}\text { UK Office for National } \\
\text { Statistics }\end{array}$ & $\begin{array}{l}\text { The Measures of National Wellbeing programme sought to create a means of monitoring well-being for the UK. It covers: personal well-being; our } \\
\text { relationships; health; work and leisure; where we live; personal finance; economy; education and skills; governance; and the environment (https://www. } \\
\text { ons.gov.uk/peoplepopulationandcommunity/wellbeing). }\end{array}$ \\
\hline United Nation (UN) & $\begin{array}{l}\text { The Sustainable Development Goals articulate a range of desirable outcomes are common internationally: no poverty; zero hunger; good health } \\
\text { and well-being; quality education; gender equality; clean water and sanitation; affordable and clean energy; decent work and economic growth; } \\
\text { industry, innovation and infrastructure; reduced inequalities; sustainable cities and communities; responsible consumption and production; climate } \\
\text { action; life below water; life on land; peace, justice and strong institutions; and partnerships (https://www.un.org/sustainabledevelopment/sustainable- } \\
\text { development-goals/). }\end{array}$ \\
\hline UN & $\begin{array}{l}\text { The Human Development Index is a composite measure of life expectancy, access to education and national income as a summary of capabilities } \\
\text { (http://hdr.undp.org/en/content/human-development-index-hdi). It is complemented by other UN indices on inequality, gender inequalities and poverty. }\end{array}$ \\
\hline
\end{tabular}

extent to which future economic growth is possible within planetary boundaries, or necessary to reduce GHG emissions, has profound implications for future population health and health inequalities, both through the impacts, this will have on the design and operation of the economy, and also through climate change impacts.

Particular economic approaches have been proposed as means to achieve ecological sustainability. Circular economies are where the outputs within a productive process are designed to form the inputs for another and, thus, do not generate waste. By contrast, linear economies which are extractive and are framed in terms of inputs, outputs and waste, and can involve the creation of wants and premature product obsolesce. ${ }^{6465}$

Doughnut economies is a way of understanding how the desirable and sustainable position for societies to live is between a social foundation and ecological ceiling (https:// www.kateraworth.com/). This means that there is a 'sweet spot' across all elements of society where there is neither excessive nor insufficient consumption to ensure that social outcomes are achieved but which avoids ecological damage. When drawn as circular segments representing aspects of political economy, this 'sweet spot' represents a doughnut with a hole.

In recognition that a change from the current economic system to an ecologically sustainable economy will create substantial change for jobs and livelihoods, the need for a Just Transition has been proposed. The International Trade Union Confederation defines a Just Transition as one which secures the future and livelihoods of workers and their communities during the transition to a low-carbon economy (https://www.ituc-csi.org/justtransition-centre). This recognises that moving from the current economy to an ecologically sustainable economy will require changes in the goods and services we produce, their distribution and, therefore, in the employment available. Doing this in a way that fully mitigates against the negative impacts that will have for workers and communities whose jobs and way of life will have to change most is important if negative health and health inequality impacts are to be avoided.

Transition towns (and workplaces, villages, cities, etc) are community-led initiatives that seek to redesign local economies to achieve ecological sustainability. They describe seven 'essential ingredients': healthy groups (learning how to work well together); vision (imagining the future you want to co-create); community involvement beyond friends and natural allies; collaborating with others; focusing on practical inspirational projects; linking up with other transition initiatives and reflecting and celebrating success (https://transitionnetwork.org/). They are examples of community-led or asset-based approaches that seek economic and environmental change that may have population health impacts both through the process followed and any changes that might result.

Even before the pandemic, there was an increasing recognition that economic growth per se was not synonymous with improving health and well-being. The United Nations, the Organisation for Economic Co-operation and Development and a selection of governments around the world (including Finland, Iceland, New Zealand, Scotland and Wales as part of the Well-being Economy Governments (https:// wellbeingeconomy.org/wego)) have set in train work to more broadly define societal progress beyond measures of economic growth (table 1).

\section{CONCLUSION}

Political economy and economic policy are important determinants of population health. As such, economic policy is too important to be left to economists and politicians. Public health priorities, methods, evidence and data should be brought to bear in this area if population health outcomes and health inequalities are to be improved in the future. 
Twitter Gerry McCartney @gerrymccartney1

Contributors $\mathrm{GM}$ and $\mathrm{OH}$ conceived the idea for this paper. GM drafted the manuscript with all RM, DS, $\mathrm{OH}$ and WH contributing substantially to the content. All authors approved the final draft.

Funding The authors have not declared a specific grant for this research from any funding agency in the public, commercial or not-for-profit sectors.

Competing interests None declared.

Patient consent for publication Not applicable.

Ethics approval This study does not involve human participants.

Provenance and peer review Not commissioned; externally peer reviewed.

Open access This is an open access article distributed in accordance with the Creative Commons Attribution Non Commercial (CC BY-NC 4.0) license, which permits others to distribute, remix, adapt, build upon this work non-commercially, and license their derivative works on different terms, provided the original work is properly cited, appropriate credit is given, any changes made indicated, and the use is non-commercial. See: http://creativecommons.org/licenses/by-nc/4.0/.

ORCID iDs

Gerry McCartney http://orcid.org/0000-0001-6341-3521

Deborah Shipton http://orcid.org/0000-0003-1997-1993

\section{REFERENCES}

1 Douglas M, Katikireddi SV, Taulbut M, et al. Mitigating the wider health effects of covid-19 pandemic response. BMJ 2020;369:m1557.

2 Marmot M, Allen J, Goldblatt P, et al. Build back fairer: the COVID-19 Marmot review. London: Health Foundation and Institute of Health Equity, 2020. https://www.health. org.uk/publications/build-back-fairer-the-covid-19-marmot-review

3 Munoz-Baell I, Alvarez-Dardet C. A call for glossaries in public health. J Epidemiology and Community Health 2000;54:561.

4 Tapia Granados JA. Economics, demography, and epidemiology: an interdisciplinary glossary. J Epidemiol Community Health 2003:57:929-35.

5 Shiell A, Donaldson C, Mitton C, et al. Health economic evaluation. J Epidemiol Community Health 2002;56:85-8.

6 Gunasekara Fl, Carter K, Blakely T. Glossary for econometrics and epidemiology. J Epidemiol Community Health 2008;62:858-61.

7 McNamara CL, Labonte R, Schram A, et al. Glossary on free trade agreements and health part 2: new trade rules and new urgencies in the context of COVID-19. J Epidemiol Community Health 2021;75:407-12.

8 Krieger N. A glossary for social epidemiology. J Epidemiol Community Health 2001:55:693-700.

9 Whitehead M. A typology of actions to tackle social inequalities in health. J Epidemiol Community Health 2007:61:473-8.

10 Eikemo TA, Bambra C. The welfare state: a glossary for public health. J Epidemiol Community Health 2008:62:3-6.

11 Harris P, Baum F, Friel S, et al. A glossary of theories for understanding power and policy for health equity. J Epidemiol Community Health 2020;74:548-52.

12 Bartley M, Ferrie J. Glossary: unemployment, job insecurity, and health. J Epidemiol Community Health 2001;55:776-81.

13 Bambra C, Fox D, Scott-Samuel A. A politics of health glossary. J Epidemiol Community Health 2007;61:571-4

14 Boulding KE. What went wrong with economics? Am Econ 1986;30:5-12.

15 Power M. Social provisioning as a starting point for feminist economics. Fem Econ 2004;10:3-19.

16 McCartney G, Popham F, McMaster R, et al. Defining health and health inequalities. Public Health 2019;172:22-30.

17 Beckfield J. Political sociology and the people's health. 1st ed. Oxford: Oxford University Press, 2018.

18 Beckfield J, Krieger N. Epi + demos + cracy: linking political systems and priorities to the magnitude of health inequities--evidence, gaps, and a research agenda. Epidemiol Rev 2009:31:152-77.

19 Solar 0, Irwin A. A conceptual framework for action on the social determinants of health discussion paper for the Commission on social determinants of health. Geneva: WHO, 2007.

20 McCartney G, Hearty W, Arnot J, et al. Impact of political economy on population health: a systematic review of reviews. Am J Public Health 2019;109:e1-12.

21 Thomas B, Dorling D, Smith GD. Inequalities in premature mortality in Britain: observational study from 1921 to 2007. BMJ 2010:341:c3639.

22 Tapia Granados JA. Macroeconomic effects on mortality: issues, controversies, and directions for research. In: Scott R, Buchmann M, Kosslyn S, eds. Emerging trends in the social and behavioral sciences. John Wiley, 2017.

23 Tapia Granados JA, Ionides EL. Population health and the economy: mortality and the great recession in Europe. Health Econ 2017;26:219-35.

24 Roelfs DJ, Shor E, Davidson KW, et al. Losing life and livelihood: a systematic review and meta-analysis of unemployment and all-cause mortality. Soc Sci Med 2011;72:840-54.
25 McKee M, Karanikolos M, Belcher $\mathrm{P}$, et al. Austerity: a failed experiment on the people of Europe. Clin Med 2012:12:346-50

26 Stuckler D, King L, McKee M. Mass privatisation and the post-communist mortality crisis: a cross-national analysis. Lancet 2009:373:399-407.

27 King L, Hamm P, Stuckler D. Rapid large-scale privatization and death rates in excommunist countries: an analysis of stress-related and health system mechanisms. Int J Health Serv 2009;39:461-89.

28 Toffolutti V, Suhrcke M. Does austerity really kill? Econ Hum Biol 2019:33:211-23.

29 van der Wel KA, Saltkjel T, Chen W-H, et al. European health inequality through the 'Great Recession': social policy matters. Sociol Health IIIn 2018;40:750-68.

30 Loopstra R, McKee M, Katikireddi SV, et al. Austerity and old-age mortality in England: a longitudinal cross-local area analysis, 2007-2013. J R Soc Med 2016;109:109-16.

31 Tapia Granados JA. Economic growth and health progress in England and Wales: 160 years of a changing relation. Soc Sci Med 2012;74:688-95.

32 Tapia Granados JA, Ionides EL. The reversal of the relation between economic growth and health progress: Sweden in the 19th and 20th centuries. J Health Econ 2008:27:544-63.

33 Lange S, Vollmer S. The effect of economic development on population health: a review of the empirical evidence. Br Med Bull 2017:121:47-60.

34 McCartney G, Fenton L, Morris G, et al. 'Superpolicies' and 'policy-omnishambles'. Public Health Pract 2020;1:100003.

35 Hodgson GM. Conceptualizing capitalism: institutions, evolution, future. Chicago: University of Chicago Press, 2015.

36 Hall PA, Soskice D, eds. Varieties of Capitalism. The Institutional Foundations of Comparative Advantage. Oxford University Press: Oxford, 2001

37 Walsh D, McCartney G, Collins C, et al. History, politics and vulnerability: explaining excess mortality in Scotland and Glasgow. Public Health 2017;151:1-12.

38 Blyth M. Austerity: the history of a dangerous idea. Oxford: Oxford University Press, 2013.

39 McCartney G, Fenton L, Minton J, et al. Is austerity responsible for the recent change in mortality trends across high-income nations? A protocol for an observational study. BMJ Open 2020;10:e034832.

40 Callen T. Gross Domestic Product: An Economy's All, 2020. Washington DC, IMF. Available: https://www.imf.org/external/pubs/ft/fandd/basics/gdp.htm

41 Sayer A, McCartney G. Economic relationships and health inequalities: improving public health recommendations. Public Health 2021;199:103-6.

42 Picketty T. Capital in the twenty-first century. Cambridge, MA: Harvard University Press, 2017.

43 McCartney G, Bartley M, Dundas R, et al. Theorising social class and its application to the study of health inequalities. SSM Popul Health 2019;7:100315.

44 McCartney Dickie G G, Escobar O, Collins C. Using inequalities in power to operationalise fundamental causes theory and focus action to reduce health inequalities. Sociology of Health and IIIness 2021;43:20-39.

45 Darity W. Stratification economics: the role of intergroup inequality. J Econ Finan 2005;29:144-53.

46 Piketty T. Capital in the twenty-first century. Cambridge, MA: Belknap Press for the Harvard University Press, 2014

47 Darity W, Mullen K. From here to equality: reparations for black America in the twentyfirst century. University of North Carolina Press: Chapel Hill, 2020.

48 Stiglitz J. Inequality and economic growth. In: Jacobs M, Mazzucato M, eds. Rethinking capitalism: economics and policy for sustainable and inclusive growth Chichester: Wiley Blackwell, 2016.

49 Christophers B. Rentier capitalism: who owns the economy and who pays for it? London: Verso, 2020.

50 Morris JN, Donkin AJ, Wonderling D, et al. A minimum income for healthy living. J Epidemiol Community Health 2000;54:885-9.

51 What is community wealth building? 2021. Manchester, CLES. Available: https://cles, org.uk/what-is-community-wealth-building/

52 What is an anchor institution? 2021. Manchester, CLES. Available: https://cles.org.uk/ what-is-community-wealth-building/what-is-an-anchor-institution/

53 Goddard J, Coombes M, Kempton L, et al. Universities as anchor institutions in cities in a turbulent funding environment: vulnerable institutions and vulnerable places in England. Cambridge J Regions Econ Soc 2014;7:307-25.

54 Cumbers A, McMaster R, Cabaço S, et al. Reconfiguring economic democracy: generating new forms of collective agency, individual economic freedom and public participation. Work Employ Soc 2020;34:678-95.

55 Cumbers A. A new definition of economic democracy - and what it means for inequality. London: London School of Economics, 2018. https://blogs.Ise.ac.uk/ businessreview/2018/03/03/a-new-definition-of-economic-democracy-and-what-itmeans-for-inequality/

56 Gibson M, Hearty W, Craig P. The public health effects of interventions similar to basic income: a scoping review. Lancet Public Health 2020;5:e165-76.

57 Citizen's Basic Income Feasibility Study Steering Group. Assessing the Feasibility of Citizen's Basic Income Pilots in Scotland: Final Report, 2020. Livingston. Available: https://www.basicincome.scot/ data/assets/pdf file/0024/175371/Draft-Final-CBIFeasibility_Main-Report-June-2020.pdf

58 Arcidiacono D, Barbera F, Bowman A. Foundational economy: the infrastructure of everyday life. Manchester: Manchester University Press, 2018. 
59 Shipton D, Sarica S, Craig N, et al. Knowing the goal: an inclusive economy that can address the public health challenges of our time. J Epidemiol Community Health 2021;75:1129-32.

60 Tomaney J, Pike A. Levelling up: a progress report. Political Insight 2021;12:22-5.

61 Graham H. Unequal lives: health and socioeconomic inequalities. Maidenhead: Open University Press, 2007.
62 Trebeck K, Williams J. The economics of arrival: ideas for a grown up economy. Bristol: Policy Press, 2019.

63 Ward JD, Sutton PC, Werner AD, et al. Is decoupling GDP growth from environmental impact possible? PLoS One 2016:11:e0164733.

64 Galbraith JK. The new industrial state. London: Penguin, 1967.

65 Jackson T. Material concerns: pollution, profit and quality of life. Abingdon: Routledge, 1996. 